\title{
Badanie stabilności termooksydacyjnej smarów plastycznych. Część 1 - smary na oleju o charakterze parafinowym
}

\begin{abstract}
W artykule przedstawiono wyniki badań laboratoryjnych odporności na utlenianie smarów litowych i polimocznikowych, wytworzonych na bazie oleju o charakterze parafinowym, z zastosowaniem dodatków przeciwutleniających o różnej strukturze chemicznej. Badanie odporności na utlenianie prowadzono zgodnie z wymaganiami normy PN-C-04143:1956 przeznaczonej dla smarów oraz przy użyciu zmodyfikowanej metody Petrooxy.
\end{abstract}

Słowa kluczowe: smary, inhibitory utlenienia, odporność na utlenianie.

\section{Determination of thermal-oxidation stability of lubricating greases. Part $1-$ Greases based on paraffinic base oil}

The article presents results of laboratory tests of the oxidation stability of lithium greases and polyurea greases manufactured on the basis of paraffinic oils, with the use of antioxidants characterized by a different chemical structure. Oxidation stability was carried out both according to the Polish Standard PN-C-04143:1956 which is dedicated to lubricating greases and with the modified Petrooxy method.

Key words: greases, antioxidants, oxidation stability.

\section{Wprowadzenie}

Smary plastyczne są układami o budowie koloidalnej, w których fazą rozpraszającą jest olej bazowy, a fazą rozproszoną substancja zagęszczająca $[4,6]$.

Faza rozpraszająca jest podstawowym składnikiem smaru plastycznego, stanowi ona $70 \div 90 \%(\mathrm{~m} / \mathrm{m})$ i decyduje między innymi o:

- właściwościach smarnych,

- zmianach właściwości w zależności od temperatury,

- odporności na utlenianie,

- właściwościach niskotemperaturowych,

- skłonności do odparowywania w podwyższonych temperaturach.

Najczęściej stosowanymi olejami bazowymi stanowiącymi fazę rozpraszającą smarów są oleje mineralne, syntetyczne oleje węglowodorowe, oleje poliglikolowe, syntetyczne estry, oleje silikonowe, tłuszcze roślinne i zwierzęce oraz estry kwasów tłuszczowych i alkoholi monowodorotlenowych lub wielowodorotlenowych (smary biodegradowalne), etery polifenylowe oraz chlorofluorowęglowodory [6].

Zagęszczacz, stanowiący około $7 \div 25 \%(\mathrm{~m} / \mathrm{m})$, w istotny sposób wpływa na parametry eksploatacyjne smaru plastycznego. W zależności od rodzaju zagęszczacza smary dzieli się na:

- mydlane, z mydłami prostymi i kompleksowymi,

- zawierające zagęszczacze mieszane,

- węglowodorowe,

- z zagęszczaczami nieorganicznymi,

- z zagęszczaczami polimerowymi [4].

W celu nadania odpowiednich cech użytkowych do smaru wprowadza się substancje modyfikujące jego strukturę i właściwości. W skład smarów plastycznych mogą wchodzić różnego rodzaju dodatki uszlachetniające, tj.: 
- modyfikatory struktury,

- stabilizatory,

- inhibitory korozji,

- inhibitory utlenienia,

- dodatki smarnościowe (przeciwzużyciowe AW - AntiWear i przeciwzatarciowe EP - Extreme Pressure),

- dodatki adhezyjne (zwiększające przyczepność smaru do metali),

- barwniki i środki zapachowe [6].

Smary litowe, zagęszczone 12-hydroksystearynianem litu, stanowią obecnie $65 \%$ wszystkich wytwarzanych na świecie smarów plastycznych [3]. Są to smary wielozadaniowe, uniwersalne i specjalne. Smary te są odporne na działanie wody, wykazują dobre właściwości ochrony przed korozją, a także charakteryzują się dobrą wytrzymałością mechaniczną (niepodatnością na wałkowanie i ścinanie). Są odporne na utlenianie, co jest istotne w przypadku pozostawania smaru w łożysku w podwyższonej temperaturze przez dłuższy czas [2, 6, 7].

Smary polimocznikowe obecnie stanowią 5\% wszystkich wytwarzanych na świecie smarów plastycznych [3]. Zostały one zagęszczone substancjami organicznymi. Charakteryzują się dobrą odpornością na działanie wody, a także na ścinanie, niewielką skłonnością do wydzielania oleju, a przede wszystkim bardzo dobrą odpornością na starzenie. Wysoka trwałość smaru podczas pracy w łożyskach związana jest z obecnością bezpopiołowego zagęszczacza, odpornego na procesy utleniania. Starzenie tego typu smarów jest wynikiem utleniania oleju $[2,7]$.

Podczas eksploatacji środek smarowy, spełniając w układzie smarowania swoje podstawowe funkcje, narażony jest przede wszystkim na działanie wysokiej temperatury. Jedną z metod zapobiegania procesowi utleniania środków smarowych jest dobór odpowiednich dodatków uszlachetniających, co gwarantuje uzyskanie wymaganej stabilności oksydacyjnej tych środków.

Dodatki przeciwutleniające (antyutleniające, inhibitory utlenienia) są substancjami, których zadanie polega na spowolnieniu degradacji smaru na skutek procesów utleniania. Smar plastyczny w czasie pracy jest w kontakcie z tlenem z powietrza, a wysoka temperatura i katalityczne właściwości powierzchni tarcia metalu stwarzają bardzo dobre warunki do utleniania. Produkty utleniania zwiększają lepkość oleju, tworząc kwaśne zanieczyszczenia o właściwościach korozyjnych oraz osady typu: żywice, laki i polimery $[1,5]$.

\section{Metodyki badawcze}

Badanie odporności smarów na utlenianie prowadzono według następujących metod badawczych:

- PN-C-04143:1956 Przetwory naftowe - Smary stałe - Badanie odporności na utlenianie,

- PN-EN 16091:2011 Ciekte przetwory naftowe - Paliwa $i$ mieszaniny ze średnich destylatów naftowych i estrów metylowych kwasów ttuszczowych (FAME) - Oznaczanie stabilności oksydacyjnej metoda szybkiego utleniania $w$ małej skali.

\section{Badanie odporności na utlenianie według PN-C-04143:1956}

Standardowa metoda badania odporności smarów na utlenianie według PN-C-04143:1956 [8] polega na utlenianiu badanej próbki w ściśle określonych warunkach ciśnienia i temperatury. W zależności od wymagań norm przedmiotowych wyraża się ją wysokością spadku ciśnienia tlenu w bombie w określonym czasie lub czasem, w którym ciśnienie spadnie o ustaloną wartość oraz zmianą zawartości wolnych zasad lub kwasów organicznych.

Badanie prowadzone jest w naczyniu ciśnieniowym, tzw. bombie (rysunek 1). Naczynka ze smarem (pięć naczynek zawierających po $4 \mathrm{~g}$ smaru) umieszcza się w statywie (rysunek 2), który następnie wkłada się do odpowiednio przygotowanej bomby. Bombę wyposażoną w manometr, w temperaturze

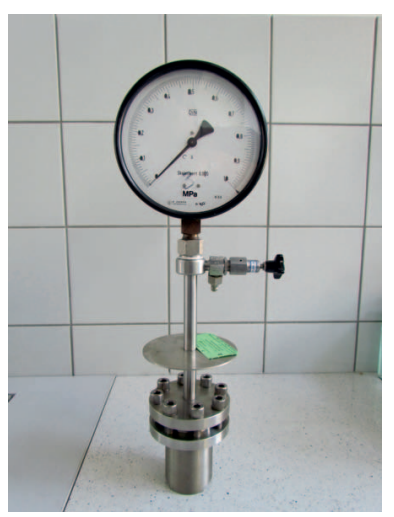

Rys. 1. Aparat do oznaczania odporności na utlenianie według PN-C-04143:1956 (fot. INiG - PIB)

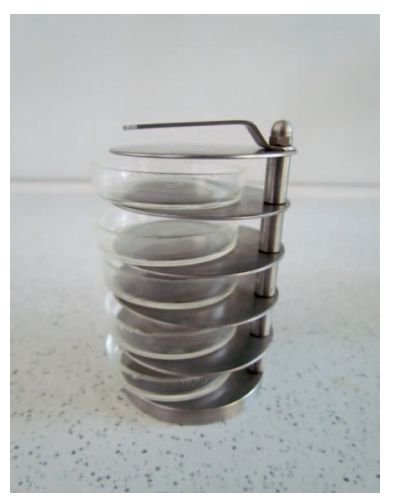

Rys. 2. Zestaw do oznaczania odporności na utlenianie według PN-C-04143:1956 (fot. INiG - PIB) 
otoczenia napełnia się tlenem do ciśnienia $700 \mathrm{kPa}$, które powoli obniża się, osiągając wartość około $50 \mathrm{kPa}$. Należy to wykonać czterokrotnie $\mathrm{w}$ celu usunięcia powietrza $\mathrm{z}$ bomby. Jeszcze raz napełnia się bombę do ciśnienia $800 \mathrm{kPa}$ i pozostawia na co najmniej $6 \mathrm{~h}$, w celu sprawdzenia szczelności. Następnie wypuszcza się z bomby część tlenu, aby uzyskać w temperaturze $100^{\circ} \mathrm{C}$ ciśnienie $800 \mathrm{kPa}$, o ile normy przedmiotowe nie określają innych warunków ciśnienia i temperatury. Bombę wstawia się do termostatu ogrzanego do temperatury badania. Moment umieszczenia bomby w termostacie należy traktować jako początek pomiaru. Od tej chwili trzeba zapisywać co 2 godziny ciśnienie tlenu w bombie, aż do osiągnięcia stałego maksymalnego ciśnienia, utrzymującego się przez okres nie krótszy niż 2 godziny. Po uzyskaniu maksymalnego ciśnienia należy dokonywać odczytu nie rzadziej niż co $18 \mathrm{~h}$. Pomiar trzeba prowadzić do określonego czasu lub do osiągnięcia ustalonej wartości spadku ciśnienia [8].

\section{Zmodyfikowana metoda Petrooxy do badania odporności na utlenianie}

Metoda Petrooxy, według PN-EN 16091:2011[9] dedykowana głównie do badania odporności na utlenianie paliw, została wykorzystana do pomiaru stabilności termooksydacyjnej smarów plastycznych. W stosunku do warunków badania paliw zmieniono następujące parametry:

- temperatura $100 \mathrm{i} 140^{\circ} \mathrm{C}$,

- ciśnienie $800 \mathrm{kPa}$,

- ilość próbki (4 g smaru).

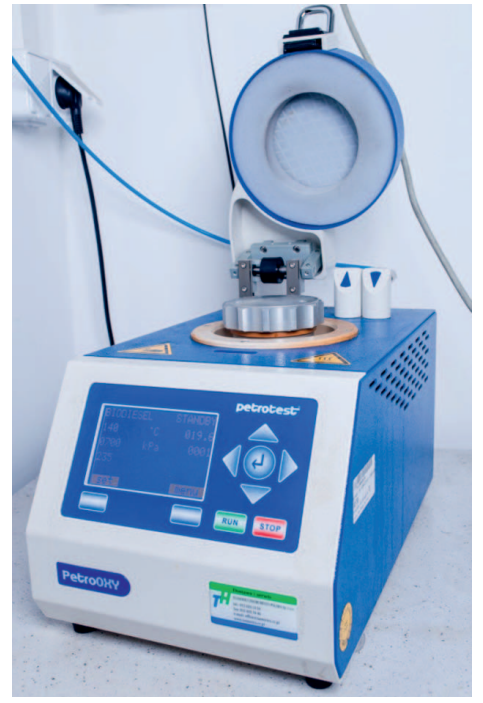

Rys. 3. Aparat do oznaczania stabilności oksydacyjnej zmodyfikowaną metodą Petrooxy według PN-EN 16091:2011 (fot. INiG - PIB)

Metoda badania polega na umieszczeniu naczynka testowego (zawierającego $4 \mathrm{~g}$ smaru) $\mathrm{w}$ temperaturze otoczenia w naczyniu reakcyjnym. Naczynie reakcyjne wstępnie przepłukuje się tlenem, a następnie napełnia do ciśnienia $800 \mathrm{kPa} \pm 5 \mathrm{kPa}$. Ogrzewa się je do zadanej temperatury (rysunek 3). Ciśnienie w naczyniu spada w miarę zużywania tlenu do utleniania próbki i jest rejestrowane w odstępach $1 \mathrm{~s}$, aż do osiągnięcia punktu załamania. Czas upływający od początku oznaczania do punktu załamania jest okresem indukcyjnym w temperaturze badania [9].

\section{Surowce do wytworzenia próbek smarów}

Surowce zastosowane do wytworzenia próbek smarów:

- olej bazowy o charakterze parafinowym, grupy I według klasyfikacji API,

- zagęszczacze:

- mydła metaliczne: 12-hydroksystearynian litu,

- organiczny: polimocznik,

- inhibitory utleniania najnowszej generacji, typu:

A - fenolowy prosty,

B - fenolowy rozgałęziony,

C - aminowy,

$\mathrm{D}$ - mieszany fenolowo-aminowy,

E - ZnDTP (dialkiloditiofosforan cynku),

$\mathrm{F}$ - karbaminian.

Właściwości oleju bazowego przedstawiono w tablicy 1 , a charakterystykę dodatków zamieszczono w tablicy 2 .
Tablica 1. Właściwości fizykochemiczne oleju bazowego

\begin{tabular}{|l|c|c|}
\hline \multicolumn{1}{|c|}{ Właściwości } & $\begin{array}{c}\text { Olej } \\
\text { bazowy }\end{array}$ & Metody badań \\
\hline $\begin{array}{l}\text { Lepkość kinematyczna } \\
\text { w temperaturze } 40^{\circ} \mathrm{C}\left[\mathrm{mm}^{2} / \mathrm{s}\right]\end{array}$ & 86,6 & PN-EN ISO 3104:2004 \\
\hline $\begin{array}{l}\text { Lepkość kinematyczna } \\
\text { w temperaturze } 100^{\circ} \mathrm{C}\left[\mathrm{mm}^{2} / \mathrm{s}\right]\end{array}$ & 10,24 & PN-EN ISO 3104:2004 \\
\hline Wskaźnik lepkości & 99 & PN-ISO 2909:2009 + Ap1:2010 \\
\hline Barwa & 1,5 & PN-ISO 2049:2010 \\
\hline Temperatura płynięcia $\left[{ }^{\circ} \mathrm{C}\right]$ & -12 & PN-ISO 3016:2005 \\
\hline Zawartość siarki $[\%(m / m)]$ & 0,551 & PN-EN 8745:2007+ Ap1:2014 \\
\hline Liczba kwasowa $[\mathrm{mg} \mathrm{KOH} / \mathrm{g}]$ & 0,01 & PN-C-04049:1988 \\
\hline Temperatura zapłonu [ $\left.{ }^{\circ} \mathrm{C}\right]$ & 270 & PN-EN ISO 2592:2008 \\
\hline $\begin{array}{l}\text { Skład grupowy węglowodo- } \\
\text { rów [\% }(m / m)] \\
- \text { węglowodory nasycone } \\
- \text { węglowodory aromatyczne } \\
- \text { związki polarne }\end{array}$ & $\begin{array}{r}77,9 \\
1,3\end{array}$ & ASTM D 2007-11 \\
\hline
\end{tabular}


Tablica 2. Charakterystyka inhibitorów utleniania

\begin{tabular}{|c|c|c|c|c|c|c|}
\hline $\begin{array}{c}\text { Nazwa } \\
\text { handlowa }\end{array}$ & A & B & $\mathrm{C}$ & $\mathrm{D}$ & $\mathrm{E}$ & $\mathrm{F}$ \\
\hline $\begin{array}{l}\text { Typ związku } \\
\text { chemicznego }\end{array}$ & fenolowy prosty & $\begin{array}{l}\text { fenolowy } \\
\text { rozgałęziony }\end{array}$ & aminowy & $\begin{array}{l}\text { mieszany fenolo- } \\
\text { wo-aminowy }\end{array}$ & ZnDTP & karbaminian \\
\hline $\begin{array}{l}\text { Związek } \\
\text { chemiczny }\end{array}$ & $\begin{array}{l}\text { 2,6-di-tert-butyl- } \\
\text { p-cresol (BHT) }\end{array}$ & $\begin{array}{l}2,2^{\prime}, 6,6 \text { '-tetra- } \\
\text { tertbutyl-4,4'- } \\
\text { methylene di- } \\
\text { phenol }\end{array}$ & $\begin{array}{l}\text { benzenamine, } \\
\text { N-phenyl-, } \\
\text { styrenated, } \\
\text { diphenylamine }\end{array}$ & $\begin{array}{c}\text { bis(4-(1,1,3,3- } \\
\text { tetramethylbutyl) } \\
\text { phenyl) amine, } \\
\text { di-octylated diphe- } \\
\text { nylamine }\end{array}$ & $\begin{array}{c}\text { zinc dialkyldi- } \\
\text { thio-phosphate } \\
\text { with primary al- } \\
\text { kyl groups }\end{array}$ & $\begin{array}{l}4,4^{\prime} \text {-methylene- } \\
\text { bis-dibutyldi- } \\
\text { thio carbamate }\end{array}$ \\
\hline \multicolumn{7}{|l|}{ Właściwości: } \\
\hline $\begin{array}{c}\text { Wygląd } \\
\text { w temperaturze } \\
20 \pm 5^{\circ} \mathrm{C}\end{array}$ & $\begin{array}{c}\text { proszek } \\
\text { barwy białej }\end{array}$ & $\begin{array}{c}\text { proszek } \\
\text { barwy żółtej }\end{array}$ & $\begin{array}{c}\text { ciecz } \\
\text { barwy żółtej }\end{array}$ & $\begin{array}{c}\text { granulki } \\
\text { jasnobrązowe }\end{array}$ & $\begin{array}{c}\text { ciecz } \\
\text { barwy żółtej }\end{array}$ & $\begin{array}{c}\text { ciecz } \\
\text { barwy żółtej }\end{array}$ \\
\hline $\begin{array}{l}\text { Temperatura } \\
\text { zapłonu }\left[{ }^{\circ} \mathrm{C}\right]\end{array}$ & 127 & $>170$ & $>230$ & 257 & $>150$ & ok. 220 \\
\hline $\begin{array}{l}\text { Temperatura } \\
\text { topnienia }\left[{ }^{\circ} \mathrm{C}\right]\end{array}$ & ok. 69 & 154 & - & 85 & - & - \\
\hline $\begin{array}{c}\text { Gęstość } \\
\text { w temperaturze } \\
20^{\circ} \mathrm{C}[\mathrm{g} / \mathrm{ml}]\end{array}$ & 1,030 & - & 1,090 & 0,99 & 1,100 & 1,060 \\
\hline $\begin{array}{c}\text { Lepkość } \\
\text { kinematyczna } \\
\text { w temperaturze } \\
40^{\circ} \mathrm{C}\left[\mathrm{mm}^{2} / \mathrm{s}\right]\end{array}$ & - & - & ok. 700 & - & ok. 150 & ok. 360 \\
\hline
\end{tabular}

Tablica 3. Właściwości smarów litowych

\begin{tabular}{|l|c|c|c|c|c|c|c|c|}
\hline \multicolumn{1}{|c|}{ Numer próbki } & SOLi0 & SOLi1 & SOLi2 & SOLi3 & SOLi4 & SOLi5 & SOLi6 \\
\hline Rodzaj inhibitora & $\begin{array}{c}\text { N } \\
\text { brak }\end{array}$ & A & B & C & D & E & F \\
\hline Właściwości: & 283 & 281 & 281 & 291 & 289 & 281 & 290 \\
\hline $\begin{array}{l}\text { Penetracja w temperaturze } 25^{\circ} \mathrm{C} \\
\text { po ugniataniu } 60 \text { razy }[\mathrm{mm} / 10]\end{array}$ & & & 2 & & \\
\hline Klasa konsystencji & 198 & 204 & 200 & 199 & 210 & 198 & 198 \\
\hline Temperatura kroplenia $\left[{ }^{\circ} \mathrm{C}\right]$ &
\end{tabular}

Tablica 4. Właściwości smarów polimocznikowych

\begin{tabular}{|c|c|c|c|c|c|c|c|}
\hline Numer próbki & SOPu0 & SOPu1 & $\mathrm{SOPu} 2$ & SOPu3 & SOPu4 & SOPu5 & SOPu6 \\
\hline Rodzaj inhibitora & $\begin{array}{c}\mathrm{N} \\
\text { brak }\end{array}$ & A & $\mathrm{B}$ & $\mathrm{C}$ & $\mathrm{D}$ & $\mathrm{E}$ & $\mathrm{F}$ \\
\hline \multicolumn{8}{|l|}{ Właściwości: } \\
\hline $\begin{array}{l}\text { Penetracja w temperaturze } 25^{\circ} \mathrm{C} \\
\text { po ugniataniu } 60 \text { razy }[\mathrm{mm} / 10]\end{array}$ & 275 & 275 & 278 & 278 & 285 & 257 & 261 \\
\hline Klasa konsystencji & \multicolumn{5}{|c|}{2} & \multicolumn{2}{|c|}{3} \\
\hline Temperatura kroplenia $\left[{ }^{\circ} \mathrm{C}\right]$ & 245 & 243 & 245 & 245 & 244 & 243 & 243 \\
\hline
\end{tabular}




\section{Sposób wytworzenia próbek do badań}

Smary bazowe ( $\mathrm{N}$ - bez inhibitorów utleniania) oraz smary zawierające dodatki antyutleniające (od A do F) wytwarzano w reaktorze o pojemności $1 \mathrm{~kg}$ i poddawano homogenizacji na młynie korundowym typu Fryma, przy szczelinie 0,2 mm.
Wytworzone smary zawierały jako zagęszczacz 12-hydroksystearynian litu, w ilości około 7\%, lub polimocznik, w ilości około $15 \%$.

Właściwości smarów przedstawiono w tablicach 3 i 4.

\section{Badanie odporności smarów na utlenianie}

\section{Metoda PN-C-04143:1956}

Wytworzone bazowe smary: litowy i polimocznikowy, oraz smary zawierające inhibitory utleniania przebadano $\mathrm{w}$ zakresie odporności na utlenianie według PN-C-04143:1956. Wyniki badań przedstawiono w tablicach 5 i 6 oraz na rysunku 4 .

Na podstawie uzyskanych wyników badań stwierdzono, że smary wytworzone $\mathrm{z}$ zastosowaniem zagęszczacza po- limocznikowego charakteryzują się lepszą odpornością na utlenianie niż smary litowe. Dla smarów litowych najskuteczniejszym inhibitorem utlenienia okazały się być dodatki typu fenolowego A i B, a najmniej skutecznym - dodatek typu karbaminianu F. Dla smarów polimocznikowych najlepszym inhibitorem utlenienia był dodatek A typu fenolowego.

Tablica 5. Odporność na utlenianie według metody PN-C-04143:1956 smarów litowych: bazowego oraz zawierających $0,5 \%(\mathrm{~m} / \mathrm{m})$ inhibitora utleniania

\begin{tabular}{|l|c|c|c|c|c|c|c|}
\hline \multicolumn{1}{|c|}{ Numer próbki } & SOLi0 & SOLi1 & SOLi2 & SOLi3 & SOLi4 & SOLi5 & SOLi6 \\
\hline Rodzaj inhibitora & $\begin{array}{c}\text { N } \\
\text { brak }\end{array}$ & A & B & C & D & E & F \\
\hline $\begin{array}{l}\text { Utlenianie } 100^{\circ} \mathrm{C} / 100 \mathrm{~h}, \\
\text { spadek ciśnienia }[\mathrm{MPa}]\end{array}$ & 0,276 & 0,010 & 0,010 & 0,019 & 0,028 & 0,013 & 0,283 \\
\hline
\end{tabular}

Tablica 6. Odporność na utlenianie według metody PN-C-04143:1956 smarów polimocznikowych: bazowego oraz zawierających $0,5 \%(\mathrm{~m} / \mathrm{m})$ inhibitora utleniania

\begin{tabular}{|l|c|c|c|c|c|c|c|}
\hline \multicolumn{1}{|c|}{ Numer próbki } & SOPu0 & SOPu1 & SOPu2 & SOPu3 & SOPu4 & SOPu5 & SOPu6 \\
\hline Rodzaj inhibitora & $\begin{array}{c}\text { N } \\
\text { brak }\end{array}$ & A & B & C & D & E & F \\
\hline $\begin{array}{l}\text { Utlenianie } 100^{\circ} \mathrm{C} / 100 \mathrm{~h}, \\
\text { spadek ciśnienia }[\mathrm{MPa}]\end{array}$ & 0,122 & 0,005 & 0,009 & 0,011 & 0,014 & 0,015 & 0,013 \\
\hline
\end{tabular}

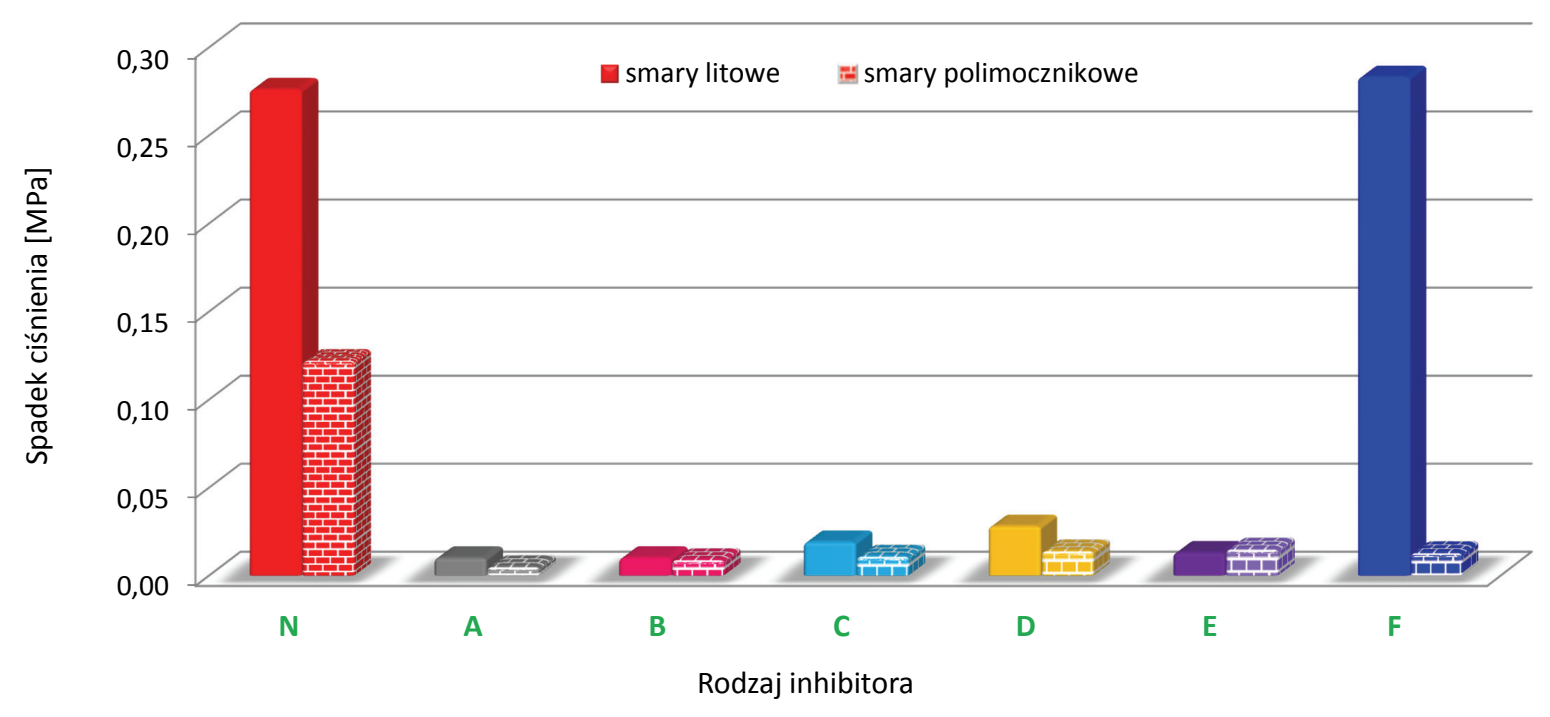

Rys. 4. Wpływ rodzaju zagęszczacza na odporność smarów na utlenianie według metody PN-C-04143:1956 
Zmodyfikowana metoda Petrooxy

Wytworzone bazowe smary: litowy i polimocznikowy, oraz smary zawierające inhibitory utleniania przebadano w zakresie odporności na utlenianie według zmodyfikowanej metody Petrooxy według PN-EN 16091:2011. Wyniki badań przedstawiono w tablicach 7 i 8 oraz na rysunkach 5-8.

W badaniu metodą Petrooxy stwierdzono, że w smarach litowych najskuteczniejszymi inhibitorami utlenienia są dodatki typu fenolowego A i B, a najmniej skuteczny jest dodatek typu karbaminianu F. Dla smarów polimocznikowych najlepszym inhibitorem utlenienia w niższej temperaturze $\left(100^{\circ} \mathrm{C}\right)$ okazał się być dodatek A typu fenolowego, a w wyższej temperaturze $\left(140^{\circ} \mathrm{C}\right)$ - dodatek $\mathrm{C}$ typu aminowo-fenolowego.

Równocześnie stwierdzono, że podwyższenie temperatury badania do $140^{\circ} \mathrm{C}$ powoduje znaczny spadek odporności na utlenianie.

W temperaturze $100^{\circ} \mathrm{C}$ smary litowe wykazują wyższą odporność na utlenianie niż smary polimocznikowe (z analogicznymi inhibitorami utlenienia), wyjątek stanowi próbka smaru zawierająca inhibitor utleniania typu karbaminianu F. Natomiast $\mathrm{w}$ temperaturze $140^{\circ} \mathrm{C}$ wyższą odpornością na utlenianie charakteryzują się smary z zagęszczaczem polimocznikowym.

Tablica 7. Odporność na utlenianie metodą Petrooxy smarów litowych: bazowego oraz zawierających $0,5 \%(\mathrm{~m} / \mathrm{m})$ inhibitora utleniania w temperaturach 100 i $140^{\circ} \mathrm{C}$

\begin{tabular}{|l|c|c|c|c|c|c|c|}
\hline \multicolumn{1}{|c|}{ Numer próbki } & SOLi0 & SOLi1 & SOLi2 & SOLi3 & SOLi4 & SOLi5 & SOLi6 \\
\hline Rodzaj inhibitora & $\begin{array}{c}\mathrm{N} \\
\text { brak }\end{array}$ & A & B & C & D & E & F \\
\hline $\begin{array}{l}\text { Ciśnienie } 800 \mathrm{kPa}, \\
\text { temperatura } 100^{\circ} \mathrm{C}[\mathrm{min}]\end{array}$ & 467 & 4156 & 4001 & 2765 & 3166 & 2888 & 584 \\
\hline $\begin{array}{l}\text { Ciśnienie } 800 \mathrm{kPa}, \\
\text { temperatura } 140^{\circ} \mathrm{C}[\mathrm{min}]\end{array}$ & 39 & 436 & 382 & 268 & 307 & 275 & 38 \\
\hline
\end{tabular}

Tablica 8. Odporność na utlenianie metodą Petrooxy smarów polimocznikowych: bazowego oraz zawierających $0,5 \%(\mathrm{~m} / \mathrm{m})$ inhibitora utleniania w temperaturach 100 i $140^{\circ} \mathrm{C}$

\begin{tabular}{|l|c|c|c|c|c|c|c|}
\hline \multicolumn{1}{|c|}{ Numer próbki } & SOPu0 & SOPu1 & SOPu2 & SOPu3 & SOPu4 & SOPu5 & SOPu6 \\
\hline Rodzaj inhibitora & $\begin{array}{c}\text { N } \\
\text { brak }\end{array}$ & A & B & C & D & E & F \\
\hline $\begin{array}{l}\text { Ciśnienie } 800 \mathrm{kPa}, \\
\text { temperatura } 100^{\circ} \mathrm{C}[\mathrm{min}]\end{array}$ & 1472 & 3361 & 2866 & 2711 & 2324 & 2245 & 2476 \\
\hline $\begin{array}{l}\text { Ciśnienie } 800 \mathrm{kPa}, \\
\text { temperatura } 140^{\circ} \mathrm{C}[\mathrm{min}]\end{array}$ & 340 & 488 & 572 & 734 & 655 & 453 & 647 \\
\hline
\end{tabular}

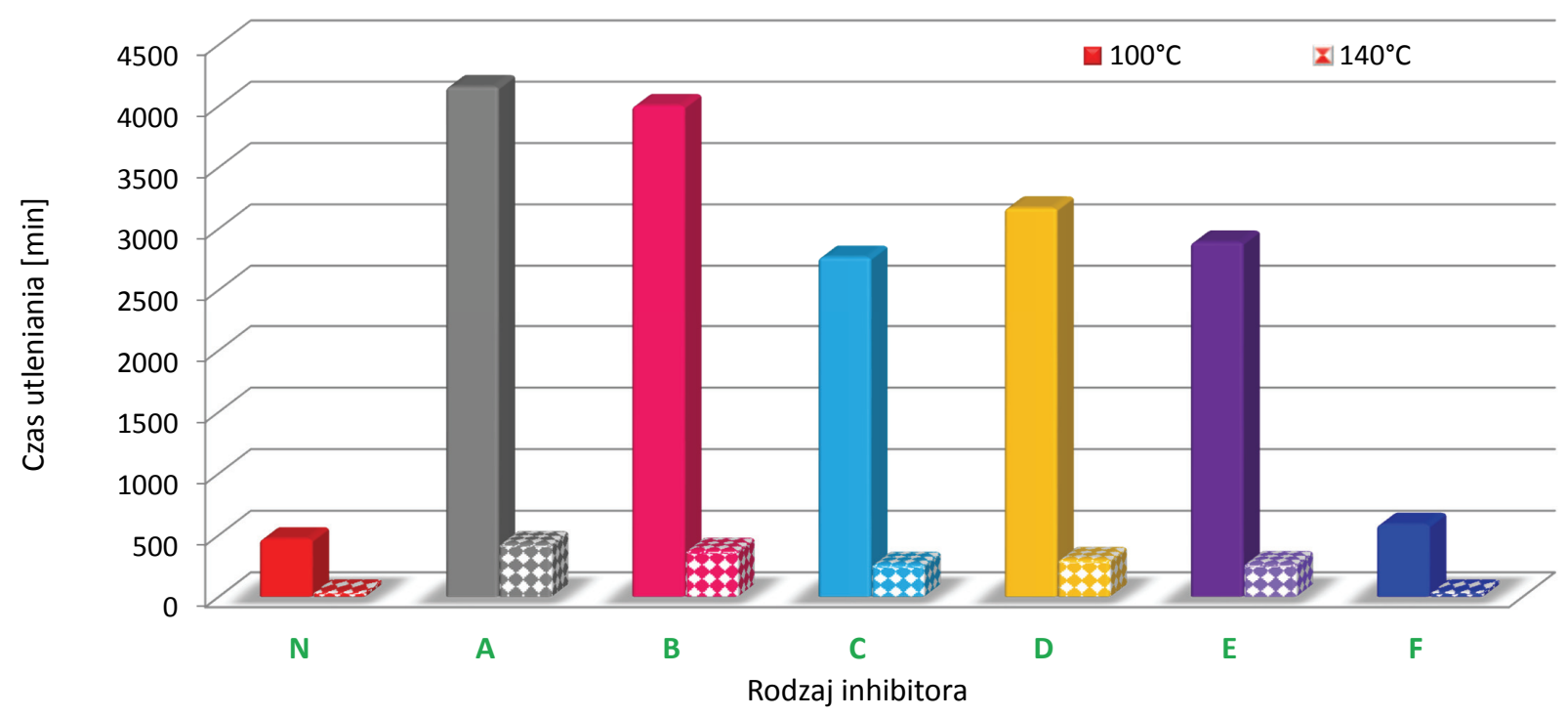

Rys. 5. Odporność na utlenianie metodą Petrooxy smarów litowych w temperaturach 100 i $140^{\circ} \mathrm{C}$ 




Rys. 6. Odporność na utlenianie metodą Petrooxy smarów polimocznikowych w temperaturach $100 \mathrm{i} 140^{\circ} \mathrm{C}$

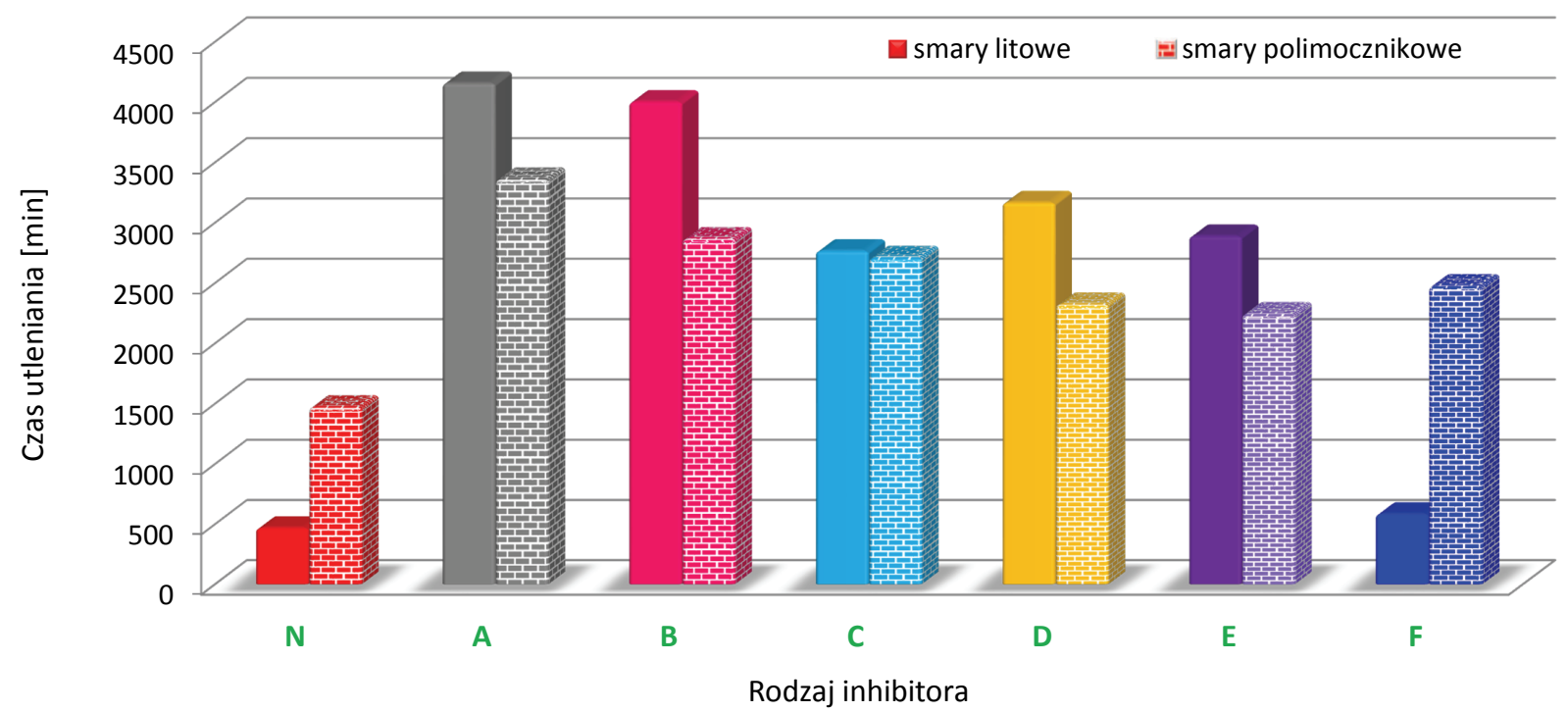

Rys. 7. Wpływ rodzaju zagęszczacza na odporność smarów na utlenianie metodą Petrooxy w temperaturze $100^{\circ} \mathrm{C}$

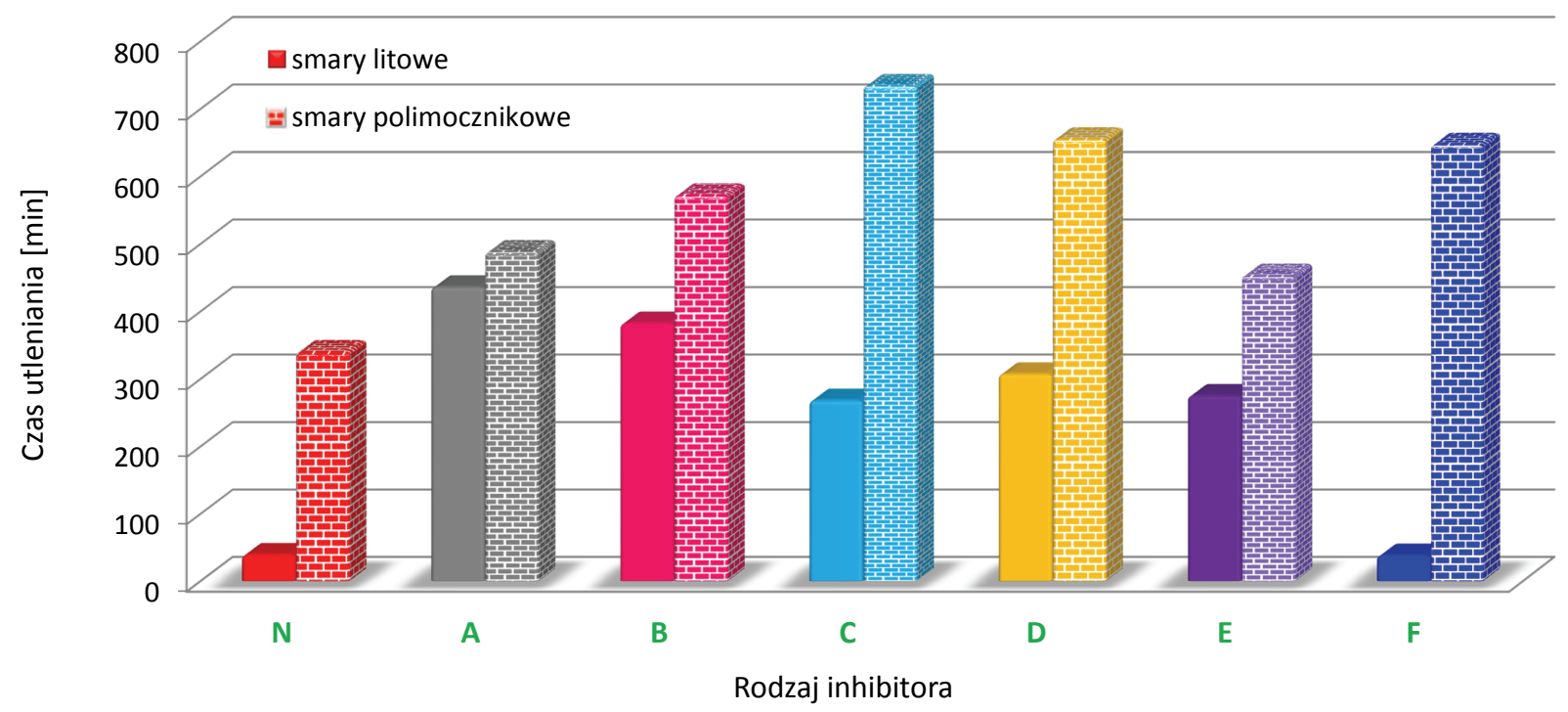

Rys. 8. Wpływ rodzaju zagęszczacza na odporność smarów na utlenianie metodą Petrooxy w temperaturze $140^{\circ} \mathrm{C}$ 


\section{Podsumowanie}

Przeprowadzono badania stabilności termooksydacyjnej smarów skomponowanych na oleju o charakterze parafinowym grupy I według API, zawierających jako zagęszczacze 12-hydroksystearynian litu oraz polimocznik, a także wzbogaconych inhibitorami utleniania o różnym charakterze chemicznym w ilości $0,5 \%(\mathrm{~m} / \mathrm{m})$.

Badanie odporności na utlenianie smarów prowadzono według metody PN-C-04143:1956 - przeznaczonej dla smarów, oraz przy użyciu zmodyfikowanej metody Petrooxy według PN-EN 16091:2011.

Stabilność smarów plastycznych może być modyfikowana poprzez wprowadzenie odpowiednich przeciwutleniaczy, których dobór zależy od rodzaju zagęszczacza smaru plastycznego oraz temperatury pracy smaru. Zmodyfikowana metoda Petrooxy jest skutecznym narzędziem pozwalającym na badanie stabilności oksydacyjnej smarów plastycznych. Badania odporności na utlenianie z zastosowaniem obu me- tod wykazały, że smary skomponowane z udziałem zagęszczacza polimocznikowego charakteryzują się lepszą odpornością na utlenianie niż smary litowe. Dodatki o strukturze fenolowej okazały się najlepszymi inhibitorami utleniania w przypadku smarów litowych, natomiast dodatek typu karbaminianu - najmniej skutecznym.

W smarach polimocznikowych badanych według PN-C-04143:1956 najskuteczniejszym inhibitorem był dodatek fenolowy prosty. Natomiast wyniki uzyskane w badaniu metodą Petrooxy dla tego rodzaju smarów różniły się w zależności od temperatury prowadzenia testu. Dla smarów polimocznikowych najskuteczniejszym inhibitorem utlenienia w niższej temperaturze $\left(100^{\circ} \mathrm{C}\right)$ okazał się być dodatek fenolowy prosty, a w wyższej temperaturze $\left(140^{\circ} \mathrm{C}\right)$ - dodatek typu aminowo-fenolowego. Równocześnie stwierdzono, że podwyższenie temperatury badania do $140^{\circ} \mathrm{C}$ powoduje znaczny spadek odporności na utlenianie.

Prosimy cytować jako: Nafta-Gaz 2016, nr 11, s. 984-991, DOI: 10.18668/NG.2016.11.13

Artykuł nadesłano do Redakcji 11.08.2016 r. Zatwierdzono do druku 6.10.2016 r.

Artykuł powstał na podstawie pracy statutowej pt. Badanie możliwości modyfikacji stabilności termooksydacyjnej smarów plastycznych - praca INiG - PIB na zlecenie MNiSW; nr zlecenia: 0007/TE/TO/15, nr archiwalny: DK-4100-7/15.

\section{Literatura}

[1] Celichowski W., Margielewski L., Płaza S.: Wstęp do tribologii i tribochemia. Wydawnictwo Uniwersytetu Łódzkiego, Łódź 2005.

[2] Czarny R.: Smary plastyczne. Wydawnictwa Naukowo-Techniczne, Warszawa 2004

[3] Grease Production Survey Report 2008-2011, NLGI.

[4] Rembiesa-Śmiszek A., Skibińska A.: Smary sulfonianowe do trudnych zastosowań. Nafta-Gaz 2012, nr 12, s. 1140-1146.

[5] Skibińska A., Żółty M.: Badanie możliwości modyfikacji stabilności termooksydacyjnej olejów bazowych. Nafta-Gaz 2015, nr 5, s. 327-336.

[6] TOTAL - poradnik, Smary plastyczne, rozdział XIX.

[7] Zajezierska A.: Smary polimocznikowe - nowoczesny gatunek smarów do wielofunkcyjnych zastosowań. Nafta-Gaz 2009, nr 1, s. 44-49.

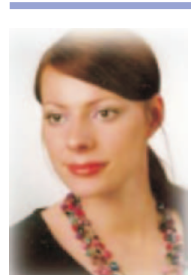

Mgr inż. Magdalena ŻÓŁTY

Specjalista badawczo-techniczny w Zakładzie Oceny Właściwości Eksploatacyjnych; kierownik Laboratorium Badań Właściwości Użytkowych.

Instytut Nafty i Gazu - Państwowy Instytut Badawczy

ul. Lubicz 25 A, 31-503 Kraków

E-mail: magdalena.zolty@inig.pl

\section{Akty prawne i normatywne}

[8] Norma PN-C-04143:1956 Przetwory naftowe - Smary stałe - Badanie odporności na utlenianie.

[9] Norma PN-EN 16091:2011 Ciekte przetwory naftowe - Paliwa i mieszaniny ze średnich destylatów naftowych i estrów metylowych kwasów tluszczowych (FAME) - Oznaczanie stabilności oksydacyjnej metoda szybkiego utleniania w małej skali.

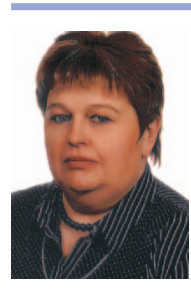

Mgr inż. Elżbieta TRZASKA

Kierownik Laboratorium Olejów, Środków Smarowych i Asfaltów w Zakładzie Olejów, Środków Smarowych i Asfaltów.

Instytut Nafty i Gazu - Państwowy Instytut Badawczy ul. Lubicz 25 A, 31-503 Kraków

E-mail: elzbieta.trzaska@inig.pl

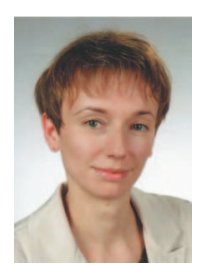

Mgr inż. Agnieszka SKIBIŃSKA

Asystent w Zakładzie Olejów, Środków Smarowych i Asfaltów.

Instytut Nafty i Gazu - Państwowy Instytut Badawczy ul. Lubicz 25 A

31-503 Kraków

E-mail:agnieszka.skibinska@inig.pl 